\title{
Tabriz on the Silk Roads: Thirteenth-Century Eurasian Cultural Connections
}

\author{
Roxann PRAZNIAK \\ University of Oregon \\ Oregon, United States \\ prazniak@uoregon.edu
}

\begin{abstract}
Tabriz under Mongol Ilkhanate rule commanded a global reach in the thirteenth-century Afro-Eurasian world. Tabriz functioned during this period not only as a commercial emporium and diplomatic center but as a seat of innovative artistic and intellectual activity.

Consideration of Tabriz as a world historical city offers insight into the economic and social dynamics that shaped a critical passage in Eurasia's history including regions of the Mediterranean and East Asian zones.
\end{abstract}

\section{Keywords}

Tabriz, Ilkhanate, Silk Road, Mongol Empire, Eurasia 
Instructors of world history courses frequently select for close study urban centers they consider to exemplify significant developments in human history. Calicut and Quanzhou, for example, are often studied for their extensive roles in the twelfth-century world economies of south and east Asia. Florence and Amsterdam of the fifteenth and seventeenth centuries respectively become locations of emergent early capitalism. Tabriz of the Ilkhanate (12561335) in Iran under the Mongol Empire is not generally singled out for such attention. I would like to suggest that Tabriz was, in fact, a striking example of a world historical city in both its cosmopolitan intellectual culture and its central role in the thirteenth-century global economy. As a form of urban organization that incorporated nomadic elements, Tabriz also expands our conception of "cities" and the factors that define a dynamic node in a global cultural matrix. How would the inclusion of Tabriz in our historical narrative expand our awareness of the processes that contributed to subsequent economic and political developments? How would it also shift our thinking about the other centers of cultural innovation that make up our discourse on world historical cities?

The claims of Tabriz to world historical status between 1256 and 1335 rest on three main categories of activity: commerce, scholarship, and diplomacy. The geographic reach of this exchange encompassed Dadu capital of the Yuan Dynasty in China, Kashmir of the Indian regions, and Siena of the Italian city-states. Included in this range are Constantinople of the Byzantine Empire, Cairo of the Mamluk lands, and Rome of the Catholic Papacy. What was the extent of commercial activity connected to Tabriz? What cultural evidence suggests far-reaching intellectual contact? And finally, at what levels of diplomatic engagement were the rulers of Tabriz involved? Tabriz rests in the spotlight because of its simultaneous, high-profile relations to each of the diplomatic and commercial 
centers of this era, a feature not equally shared by any one of the other centers. ${ }^{1}$

\section{COMMERCIAL NETWORKING}

Tabriz had its own unique geographic features, contributing both to its commercial importance and its relatively underdeveloped condition prior to the Mongol's arrival and its sudden rise to prominence after 1250. Located on major routes along the silk road networks approximately 150 miles west of the southern Caspian Sea, Tabriz became a significant commercial crossroads under the Abbasid rulers of the early ninth century. Situated in the eastern corner of an alluvial plain with the Caspian Sea to the east and the Sahand massif with peaks of 11,0oo feet to the south, Tabriz functioned as the only suitable pass in the area for east/west and south/north trade routes. Prone to earthquakes, Tabriz suffered numerous tremors including one in 1042 when an estimated 40,000 people died. The years 1273 and 1304 also witnessed major quakes that destroyed a large number of buildings in the city. ${ }^{2}$ While Tabriz had many streams and rivers that could be used for irrigation, these ran dry during the summer months. Water too salty for drinking was also a problem. For its main water supply, Tabriz depended on a system of underground water canals (qanâts) that tapped into subterranean water channels and carried drinking water directly to neighborhoods. Local elites with resources constructed and maintained cobbled conduits as part of their charita-

\footnotetext{
${ }^{1}$ The literature on Ilkhanid commercial and diplomatic relations is extensive. Key references include: Thomas T. Allsen, Culture and Conquest in Mongol Eurasia (Cambridge: Cambridge University Press, 2001); Morris Rossabi, The Mongols and Global History (New York: W.W. Norton, 2010); Julian Raby and Teresa Fitzherbert, eds., The Court of the Il-khans (Oxford: Oxford University Press, 1996); Reuven Amitai-Press and David O. Morgan, eds., The Mongol Empire and Its Legacy (Leiden: Brill, 1999); Denise Aigle, ed. L'Iran face a la domination mongole. Bibliotheque Iranienne, 45. Tehran, 1997.

2 Ann K.S. Lambton, Continuity and Change in Medieval Persia, Aspects of Administrative, Economic, and Social History, $11^{\text {th }}-14^{\text {th }}$ Century (New York: SUNY Press, 1988), 167.
} 
ble activities. Periodic fees contributed to repairs. Families could be charged according to the number of pipes entering a household. Without major political investments, Tabriz remained a sizeable and important hub of trade but was not a world historical city. This investment came with the Mongol invasions. The region just south of Tabriz known as the Mughan Steppe was ideal pastureland for the Mongols' vast herds, a necessary requirement for rulers with a nomadic lifestyle. In addition to its strategic commercial location, Tabriz offered tactical advantages in the Ilkhan's watch over its northern border with the Golden Horde. The Mongol destruction of Baghdad in 1258 secured Ilkhan Hülegü's selection of Tabriz as the region's new political center. Once a place in the string of commercial, urban centers that dotted central Eurasia, Tabriz became an imperial center. Thus augmented and accentuated, Tabriz's status would remain a marker of political authority long after the Mongols had passed from the scene.

Under the Ilkhans who governed as "subordinate khans" to the Mongol Khans of Cathay, Tabriz became a magnificent city with a large population and a collection of newly constructed imperial buildings. Because the Atabeg rulers of Tabriz submitted peacefully to the Mongols in 1231, the city with its many shrines to sufis, poets, and mystics in addition to its commercial assets suffered little destruction. With the advent of Mongol rule, the city expanded well beyond its existing walls with the addition of many new neighborhoods, gardens, and orchards. Many Ilkhanid ministers and local governors contributed to both secular and religious construction projects in Tabriz; some of these buildings functioned as palace complexes with new administrative offices. ${ }^{3}$

All of the Ilkhans maintained their nomadic lifestyle and seasonal migrations to accommodate their herds. Consequently, the royal households periodically vacated Tabriz leaving only minimal official staff behind. Tabriz, however, was a city associated with the

${ }^{3}$ Fariba Zarinebaf-Shahr, "Tabriz Under Ottoman Rule," (PhD diss., University of Chicago, 1991), 48. 
court even when the court was elsewhere. This gave the city a particular dynamic and vitality. Rashid al-Din, a historian of the period, wrote that, “. . . Tabriz was so populous that it became an Egypt with Arghunia as the capital like Cairo." "Tabriz, in this case, refers to both the city and the district (tuman). The whole of Azerbaijan province in which Tabriz was located was comprised of nine tumans with twenty-seven cities; Tabriz itself constituted seven districts each with numerous villages. ${ }^{5}$ Sultaniyya also known as the Arghunia mentioned above was developed by the Ilkhans of Tabriz. Of it the geographer Mustawfi wrote in 1340: "There are at the present time so many great buildings in Sultaniyyah, that, except for Tabriz, the like thereof is seen in no other city. People also have migrated hither from many other provinces, to settle in the (new) capital, being of all nations and sects, whereby the language spoken at present here is not uniform, though it is mainly a mixed dialect of Persian." Many contemporary travel accounts concur in this depiction of Tabriz as the finest and largest city in all of Iran, the heartland of the western Mongol Empire. The prized yellow plums of Tabriz, like the peaches of Samarkand, were a signature agricultural product, not to be found any place else in the world.

While the Ilkhans' political ties to the Yuan rulers were crucial, Tabriz owed its evolution into a world historical city to its selective cultivation of Chinese and Mongol cultural elements in the Iranian heartland of Islam and in proximity to expansive European interests. Tabriz was a city under the authority of nomads who placed a premium on networks of exchange and the promotion of institutions and cultural formations that facilitated that exchange. Expanding on the Islamic waqf system (charitable endowments) to build a commercial infrastructure for Tabriz, Ilkhan

${ }^{4}$ Rashiduddin Fazlullah, Jami' u't-tawarikh: Compendium of Chronicles, translated and annotated by W.M. Thackston (Harvard University: Department of Near Eastern Languages and Civilizations, 1999), 577.

${ }^{5}$ Hamd-Allah Mustawfi of Qazwin, The Geographical Part of the Nuzhat-al-Qulub (1340), tran. G. Le Strange (Leyden: E.J. Brill/E. J. W. Gibb Memorial Trust, 1919), 78, 82.

${ }^{6}$ Hamd-Allah Mustawfi of Qazwin, 61 
Ghazan oversaw the construction of a covered bazaar that both enhanced trade and incorporated new mosque and madrasa educational structures. The waqf system legally endowed public buildings traditionally devoted to religious activity. Because such structures typically included mosques, schools, and markets, Ghazan's expansion of the commercial component was significant but built on familiar practices. Spanning an area of twenty-nine acres, the covered bazaar of Tabriz became the largest bazaar for hundreds of miles around. ${ }^{7}$ Silk weavers maintained workshops in the bazaar, while camel sellers, jewelers, dye, carpet, and sugar merchants found their place along with money-changers, book and paper sellers, and leather-makers. An extensive system of caravanserai provided traveling merchants with accommodations, information, and resources. Without the system of charitable endowments supported by secular and religious leaders, the commercial infrastructure of Tabriz could not have been possible.

In 1273 a new mint master arrived in Tabriz. Known from the design of his insignia as Master Arabesque and possibly of Georgian origins, he set in motion far reaching fiscal reforms. Financial institutions were an instrument of both commercial and political strength as well as the means for sponsoring cultural activity. Plans for monetary reform in Tabriz had begun in the early 1270s. Almost a decade would pass before their completion with numerous difficulties along the way. The goal was to create a coinage system for Tabriz that by extension would transform exchange across the Ilkhanate. Beyond standardizing silver coins by weight, design, and quality, Master Arabesque introduced an ideological approach to financial reform. Coins would be minted in copper and gold to cover all media of market exchange from the Mediterranean to the Indian Ocean and South China coast. As Judith Kolbas has written, in developing a design for the new coins, "the mint master planned

${ }^{7}$ Fariba Zarinebaf-Shahr, "Tabriz Under Ottoman Rule" (Ph. Diss., University of Chicago, 1991), 74 . 
to adopt both Mongol and Islamic concepts to give Tabriz the status of a capital in both cultures."

. . . both the reverse and obverse of the 671h Tabriz type announced a new unified financial structure of the whole regime. The two words of al-adil and al-azam re-asserted the Chingizid tradition from the east as well as combined the two different administrative regions of the west. On the obverse, the amalgamation of the short shahada from Adharbayjan with the longer ones from the il-khan's province also joined two regions. As a result, both sides of the coin gave a political statement of unity. ${ }^{9}$

The standardization of weight greatly facilitated exchange both within the Ilkhanate and with neighboring economies. Beyond increased ease of monetary exchange, new coinage signified new political authority. The poll tax and customs duty were essential to raise revenue from the diverse populations, just as tribute had been essential for steppe governance. Sundry ethnic and religious groups could be incorporated into one tax system resulting in increased revenue for a stronger state and the projects it sponsored. This was especially critical because the Mongols had destroyed much of their potential tax base in the wanton destruction of agricultural and village life during the initial period of conquest. Ironically, it was in the effort to undo this destruction that Ghazan imported Chinese agricultural knowledge into Iran. Land taxes both agricultural and pastoral were paid primarily in kind; religious orders and the political/military elite held tax exemptions.

Fiscal reform and political patronage catapulted Tabriz to a world class city that functioned as a major commercial nexus of the silk road emporia facilitating the growth of new markets in Burgundy and Tuscany and augmenting the already well-developed

${ }^{8}$ Judith Kolbas, The Mongols in Iran: Chingiz Khan to Uljaytu 1220-1309 (London: Routledge, 2006), 200, 201, 205.

${ }^{9}$ Ibid., 203-4. 
markets of Cathay, India, and eastern Iran. Wealthy merchants and church figures drawn from the periphery of the empire all sought luxury textiles from the Tabriz domestic and import markets including the highly prized nasij gold brocade. ${ }^{10}$ The papal inventory of 1295 included silks manufactured in Tabriz, and Emperor Rudolf IV of Habsburg was buried in 1365 in silk woven in Tabriz between 1319 and $1335 .{ }^{11}$ Economic historian A.P. Martinez has noted that, "The transit trade between India and the West was always the most important single category of trade in the Il-Khanate"; he goes so far as to say that, "The India trade of the Latin West was responsible for the prosperity of the Il-Khanate." ${ }^{12}$ With Ilkhan Hülegü's capture of Baghdad and the end of the Abbasid Caliphate in 1258, prosperous trade routes between Baghdad and Sind shifted to Tabriz and the Black Sea under Mongol rule. Trade through the Persian Gulf port of Basra previously destined for Baghdad now continued on to Tabriz. Earliest evidence of detailed geographic interest in Iran among Italian elites comes to us in Vesconte's 1321 map of Persia showing the Tigris and Euphrates rivers. Created for the Papacy in Rome, this map was presented as part of a project to emphasize central Asian trade routes as an alternative to Mamluk Egypt for goods imported from south and east Asia. Having repeatedly restricted trade with the Mamluks, the Papacy in 1323 finally banned all trade with Alexandria to the dismay of Venetian merchants in particular. As a substitute option, the Papacy sought to promote both trade and missionary work in the Ilkhanate. ${ }^{13}$ With the ascent of Pope Nicholas IV [1288-92], the first Franciscan pope, many friars of the Franciscan order were active in Ilkhanid Iran, in-

${ }^{10}$ T. Allsen, Commodity and Exchange in the Mongol Empire: A Cultural History of Islamic Textiles (Cambridge: Cambridge University Press, 1997).

${ }^{11}$ David Jacoby, "Oriental Silks Go West: A Declining Trade in the Later Middle Ages," in Islamic Artefacts in the Mediterranean World: Trade, Gift Exchange and Artistic Transfer, ed. Catarina Schmidt Arcangeli and Gerhard Wolf (Venezia: Marsilio, 2010), 72, 73.

12 A.P. Martinez, "The Eurasian Overland and Pontic Trades in the Thirteenth and Fourteenth Centuries," Archivum Eurasiae medii aevi 16 (2008/2009), 152.

${ }^{13}$ A.P. Martinez, "The Eurasian Overland and Pontic Trades in the Thirteenth and Fourteenth Centuries," Archivum Eurasiae medii aevi 16 (2008/2009), 164. 
cluding Tabriz. ${ }^{14}$ Pietro Veglione (or Vilione), a Venetian trader, lived in Tabriz in 1264 and acted as contact person for a number of merchants working commercial routes between Tabriz and the Italian city-states. The Papacy also established bishoprics at Maragha and Sultaniyya in the greater Tabriz region. John de Cora, appointed Archbishop of Sultaniyya by Pope John XXII in 1330, wrote an account titled Livre de l'Estat du Grand Caan between 1328 and 1334 in which he commented on the ecclesiastical organization of the Buddhists in Sultaniyya under their Grand Lama: "This pontiff of idolaters was dressed like a cardinal; 'porte sur son chief un chapeau rouge, et touslours est vestu de rouge' [wearing on his head a red hat, and dressed in red]."15

Products from Kashmir, Nepal, and Tibet were in high demand along the Tabriz routes as were condiments, aromatics, medicines, and dyes from south Asian markets. Musk from Tibet was at this time comparable in value to the luxury silks that travelled the northern trade routes between Tabriz and China. Marco Polo returned through Tabriz to Venice with Tibetan musk as one of his commercial assets acquired on his travels. The musk trade moved along routes from Tibetan and northern Hindu lands by sea from Sind to Basra on the Persian Gulf or across land through Herat and Sultaniyya to Tabriz. Hindu communities along the Tabriz to northern India route facilitated this trade. Hamd-Allah Mustawfi of Qazwin, geographer and tax collector for the Ilkhanate, noted in 1340 that in Isfahan "The fruits from here are exported to India and to Greece." ${ }^{16}$ Another commodity noted by Mustawfi was rock crystal, highly prized for light fixtures and precious carvings. "This

${ }^{14}$ Shelia Blair, "Religious Art of the Ilkhanids," in The Legacy of Genghis Khan: Courtly Art and Culture in Western Asia, 1256-1353, ed. Linda Komaroff and Stefan Carboni (New Haven: Yale University Press, 2002/ New York: The Metropolitan Museum of Art, 2002), 112.

${ }^{15}$ C. Raymond Beazley, The Dawn of Modern Geography: A History of Exploration and Geographical Science from the Middle of the Thirteenth to the Early Years of the Fifteenth Century (ca. A.D. 1260-1420), vol. III (1906; New York: The Clarendon Press, 1949), 209 note 7.

${ }^{16}$ Hamd-Allah Mustawfi of Qazwin, The Geographical Part of the Nuzhat-al-Qulub (1340), trans. G. Le Strange (Leyden: E.J. Brill/E. J. W. Gibb Memorial Trust, 1919), 56. 
is found in India," he wrote, "in the mountains of the province of Kashmir. It is also found in the hills of the Frank countries, but though in the Frank country it is found in greater abundance, the best is the Indian Rock-crystal."

\section{CULTURAL REACH}

The cross-cultural dialogue supported at the court of Tabriz was remarkable. One treatise by Rashid al-Din on Reason and Science and which is preferable recorded the views of Muslim, Jewish, Christian, and Buddhist scholars. The nature of the inquiry focused on the relationship between reason and science. The two were not assumed to be synonymous. Quite the contrary, there was a preference for arguments which held that "human reason" was higher than "abstract reason." Only the Christian perspective seemed to homogenize the two into a notion that humans might aspire through both to the realm of the divine. ${ }^{17}$ Rashid al-Din based his discourse on questions send to scholars throughout the Ilkhanate and some neighboring territories including the Basins of Sind and Tarim. To support scholarly communities, the Ilkhans designated tribute gifts from Constantinople and Venice for use by villages in Tabriz that housed international students and teachers. Consequently, many of the scientific and medical books produced in Tabriz circulated widely and were commonly translated into Greek and other languages.

The Tabriz manuscript workshops, made fiscally possible by a secularized version of the Islamic waqf (pious foundation) brought together artists of Persian and Buddhist training to celebrate Mongol authority. ${ }^{18}$ Vizier Rashid al-Din with imperial sponsorship began to produce the illustrated manuscript known as the Jami' al-

${ }^{17}$ Zeki Velidi Togan, “A Document concerning Cultural Relations between the Ilkhanide and Byzantiens" in Ilhanli Bizans Kultur Munasebetlerine dair Vesikalar (Istanbul: Islam Tetkikleri Enstitusu Dergisi IV. Cildine ektir, 14, 1965), 9, 15.

${ }^{18}$ Mazhar Sevket Ipsiroglu, Painting and Culture of the Mongols (New York: Harry N. Abrams, Inc., 2000), 11-14. 
Tavarikh [A Compendium of World History] in 1304. This work, in its conceptualization and execution, was bold and innovative. Inspired by the Han-lin Academy in Chinese historical writing and initially proposed by Qubilai Khan's staff, the Jami'al-Tavarikh took on distinctive features in its Iranian setting and surpassed the limits of its original conception. The novel idea of integrating diverse histories into one inclusive narrative project set a new standard for historical thinking. Rashid al-Din's histories of India and Christendom [both Byzantine and Latin] were completed with the assistance of scholars from Indian and Christian communities in Tabriz. ${ }^{19}$ Chinese artisans and translators inhabited a quarter in Tabriz in the late thirteenth and early fourteenth centuries. ${ }^{20}$ Kashmiri Buddhist monk Bakshi Kamalashri worked at the Ilkhanid court alongside scholars and monks from Byzantium and regions of the eastern Mediterranean. An illustration of the Virgin Mary in the Jami 'al-Tavarikh of 1304 shows Mary with a BuddhistZoroastrian fire halo. In the same volume the Buddha appeared in Arabic dress, and a scene from his life was set in a contemporary Islamic setting with a Sufi mosque. Another illustration depicted the birth of Mohammed, drawing on conventions for the representation of the birth of Christ. Within the artistic traditions of Islam, illustration of the human form was itself a radical departure from orthodoxy, and Tabriz was at the center of this artistic innovation.

The tremendous wealth of Tabriz played a crucial role in the extensive sponsorship of Buddhism and art in the region. It is estimated that the Ilkhanid court spent nearly half of its state revenue on the construction and furnishing of Buddhist temples and the support of Buddhist religious communities. This included the Buddhist temple complex of Labnasagut on the northeast of Lake

${ }^{19}$ Anthony Welch, "The Arts of the Book," in Treasures of Islam (Museum of Art History, Geneva: Sotheby’s/Philip Wilson Publishing, 1985), 49.

${ }^{20}$ Karl Jahn, "Paper Currency in Iran," Journal of Asian History 4, no. 2 (1970): 131; T.F. Carter, The Invention of Printing in China and Its Spread Westward (New York: Ronald Press, 1955); K. Jahn, "Tabris, ein mittelalterliches Kulturzentrum zwishchen, Ost und West," Abhandlugen der Osterreichischen Akademie der Wissenschaften 105 (1969): 209. 
Van in Armenian territories, constructed in 1260-61and described by a contemporary traveler in this way:

Hülegü built a temple for huge idols, collecting there all kinds of craftsmen-stone masons, carpenters and artists. And there is one group [among them] which are called toyins. ...All of them are priests; they shave the hair of the head and the beard [and] they wear on the breast yellow cloaks and they worship all, but most of all Sakyamuni and Maitreya. ${ }^{21}$

A new and more attentive awareness of Buddhism in central and western Eurasia was one of the primary cultural consequences of Ilkhanid rule in Tabriz. Individuals like Roger Bacon and Marco Polo were seriously interested in the precepts of Buddhism for its philosophical and political connotations. The interest of some stemmed more from interest in potentials for conversion to Christianity. An extant copy of the Lotus Sutra dated 1346 with gold frontispiece illustrating the life of the Buddha found its way to a shelf in the Vatican Library, underscoring the many levels and directions of cultural exchange that circulated through and around Tabriz. ${ }^{22}$ Travelers among Christian communities through Tabriz, Armenia, and Rome transmitted images of Ilkhan Hülegü and Doquz Khatun reimagined as the new Constantine and Helen, parents of Constantine the Great founder of the Byzantine Empire. One of these illustrations also found its way to the Papal offices in Rome.

The cosmopolitan society and world vision emanating from Ilkhanid Tabriz found its reflection in the less cosmopolitan but world aspiring regions of western Eurasia including Tuscany and Siena in particular. While Tomasso Uzi served the court of the

${ }^{21}$ Thomas T. Allsen, Technician Transfers in the Mongolian Empire (Bloomington, Indiana: The Central Eurasian Studies Lectures, Indiana University, 2002), 14, 15.

${ }^{22}$ Lauren Arnold, Princely Gifts and Papal Treasures: The Franciscan Mission to China and Its Influence on the Art of the West, 1250-1350 (San Francisco: Desiderata Press, 1999), 2829. 
Ilkhans, Ambrogio Lorenzetti, a fellow Sienese and artist dependent on the Sienese commercial and political elite for patronage, created his fresco The Martyrdom of the Franciscans in 1342. He chose as his setting a contemporary central Asian court, and he illustrated a remarkably detailed awareness of the cosmopolitan make-up of that world. Ambrogio Lorenzetti's Martyrdom scene set in a Mongol court reflects back the "whole cloth" vision of a global project similar to that projected in the illustrated texts of Tabriz. Both convey a historically-based, contemporary, and universal humanism that crossed geographic and hence political as well as cultural divides. These could be cases of independent simultaneous thinking or a matter of co-creation in a shared and expanding field of cultural and geographic awareness. Simone Martini at the same time in Siena developed new painting techniques to more accurately depict light-reflecting qualities of the highly-prized nasij gold brocade, the signature creation of Mongol textile production. With great attention focused on the products and politics of Tabriz, micro cultural adjustments across the region absorbed and were transformed by elements emerging from the Mongol era of material and social cultural exchange.

\section{DIPLOMATIC ENGAGEMENT}

The languages at the Ilkhanid court in Tabriz included Hindi, Kashmiri, Tibetan, Greek, Italian, and Arabic among others, making possible extensive diplomatic engagement at both the formal and informal levels. Although the Mongol rulers at Dadu remained the center of the Mongol political world, Tabriz maximized its cultural and diplomatic reach by extending its networks beyond Dadu to every major polity on the boundaries of the Ilkhanate from Sind to Rum into the Frankish territories. While Dadu maintained relations with all of the latter as well, the immediacy of commercial and military issues between the Ilkhans and the rulers to their west made for more intense, complex engagement. 
Like the Yuan rulers, the Ilkhans followed the Mongol policy of drawing on expertise from all sources and actively coordinating talents in an attempt to support the Mongol's ideological trope of world conquest. Scholars, artisans, and agricultural specialists were sent out from the Yuan court to Tabriz including some artists and scholars who worked on the already mentioned world history volumes. The Mongolian official Bolad, who came to serve the Ilkhans after holding high positions at the Yuan court, contributed to a large experimental garden near Tabriz designed to stimulate Iranian agriculture by introducing new techniques and seeds from China and India. In the area of medicine Bolad and Rashid al-Din, vizier to the Ilkhans, established a large hospital in Tabriz and translated such works as the fourth-century Chinese manual on The Secrets of the Pulse. When the Ilkhanate began to experience a major fiscal crisis, Bolad introduced the use of paper money into Iran, based on Chinese economic practices, but without success. ${ }^{23}$

Merchants and religious figures traveled the paths between Tabriz and the central Italian city-states in significant numbers providing an infrastructure of translators and cultural experts for the more formal aspects of diplomacy. Some like Tomasso Uzi from Siena found employment as sword bearer to the Ilkhan and served in the inner court. ${ }^{24}$ In his capacity as translator to the Ilkhan in business matters, Uzi served as a more neutral interpreter of conflicts and requests that commonly involved disputes between the Venetians and Genoese. The above mentioned John de Cora, Archbishop of Sultaniyya, conducted church diplomacy, preparing reports for Rome on conditions and events around Tabriz and representing Roman Christianity to the Ilkhanid court. Rabban Sauma

${ }^{23}$ Thomas T. Allsen, "Biography of a Cultural Broker, Bolad Ch'eng-Hsiang in China and Iran," in The Court of the Il-khans, 1290-1340, ed. Julian Raby and Teresa Fitzherbert (Oxford: University of Oxford Press, 1996), 15-18.

${ }^{24}$ Nicola di Cosmo, "Mongols and Merchants on the Black Sea Frontier in the Thirteenth and Fourteenth Centuries: Convergences and conflicts," in Mongols, Turks, and Others: Eurasian Nomads and the Sedentary World, ed. Reuven Amitai and Michal Diran (London: Brill, 2005), 410. 
left Dadu as a Nestorian monk on pilgrimage to the Holy Lands, but upon his arrive in Tabriz was dispatched by the Ilkhanid court as a diplomat to the French and English courts as well as the Papal court. In 1288 with Rabban Sauma's return to Tabriz, Philip IV sent a church tent equipped with religious pictures as a diplomatic gift to Ilkhan Arghun. ${ }^{25}$ Nomadic society depended on magnificent portable wealth including art for the mobile lifestyle of the elite, and this seems to have registered in matters of diplomatic exchange.

The Ilkhans were assertive at the level of state-to-state diplomacy as well. Repeatedly they sent missions to the Latin West seeking an alliance with the papacy and the Christian heads of state against the Mamluk sultanate in Egypt. The Mamluk sultans were allied closely with the Ilkhanate's Mongol enemies to the north of Tabriz in the Golden Horde, a forth division within the post -126o divided Mongol empire. Abaqa sent several embassies, notably at the time of the Lateran council of 1274. Ilkhan Arghun in turn sponsored missions to the West, the most important of which was the above mentioned delegation headed by the Nestorian monk Rabban Sauma in 1287. In 1299 he sent letters, in Mongolian and Latin, to the Papacy and to King Philip IV of France. Neither of these efforts met with success. Nor did the Ilkhan's repeated correspondence to the Mamluk rulers offering them opportunities for surrender to Mongol authority find a receptive audience. Before his campaigns of 1299-1300 against the Mamluks, Ilkhan Ghazan contacted the king of Cyprus, Henri II de Lusignan, in the hope of obtaining military assistance. The Ilkhan later exchanged letters and embassies with Pope Boniface

${ }^{25}$ Pier Girogio Borbone, "The Church at the Court of Arghun in Syriac and Armenian Sources," in Bazmavep, forthcoming. On Rabban Sauma also see, Morris Rossabi, Voyager from Xanadu, Rabban Sauma and the First Journey from China to the West (Berkeley: University of California Press, 2010) and Rabban Sauma, Monks of Kublai Khan, Emperor of China: Medieval Travels from China through Central Asia to Persia and the Arab World, trans. Wallis Budge, (London: I.B. Tauris, 2013). 
VIII with the objective of forming a united front against the Mamluks. Oljeitu too, in 1305, long before his invasion of Syria in 1312, sent letters to the kings of France and England with the same purpose in mind. After the Mamluk defeat of Ilkhan Öljeitü's forces in Syria in 1313, the Ilkhans ceased military actions, and for all practical purposes warfare between these two foes came to an end.

As centers of Christian authority, Rome and Constantinople were both relatively weak states; Constantinople, however, enjoyed a higher status in Eurasian diplomatic circles. The Ilkhans shared in this assessment, and their efforts to create an alliance with Rome amounted to an attempt to draw a more peripheral player to their side. The Byzantines were also not available. Unlike the Roman Church fathers, the rulers of Byzantium maintained informal diplomatic connections with the Mamluks through Orthodox Church channels in Cairo. ${ }^{26}$ The Ilkhans, like their enemies the Mamluks, recognized Byzantine emperors as heirs to the Kingdom of Alexandria, Greek learning, and the Ancient Roman empire all of which Ilkhanid court intellectual circles held in high regard. In other words, Byzantium represented a political center in the Mediterranean world that remained a reference point for inter-state diplomacy even when the Byzantine Empire was in reality in decline. ${ }^{27}$ In the view of the Mamluks and Ilkhans, Constantinople held its status as the highest seat of Christianity and as such retained the privilege of distributing thrones and crowns within Christian lands. Both the Ilkhans and the Mamluks claimed diplomatic friendship with the Byzantine rulers and sought to cultivate this relationship. For the Mamluks, the Byzantines were friendly Christians, but not active allies. The Ilkhans sought to maintain their own good relations with Constantinople, and marriage diplomacy was their modus operandi. Diplomatic marriages between the Ilkhans and the daughters of the Byzantine rulers strengthened defense on the

${ }^{26}$ Dimitri A. Korobeinikov, "Diplomatic Correspondence between Byzantium and the Mamluk Sultanate in the Fourteenth Century," Al-Masaq 16, no. 1 (March 2004): 53.

${ }^{27}$ Dimitri A. Korobeinikov, Al-Masaq 16, no. 1 (March 2004): 57-58. 
Ilkhanate's northern border where conflict with the Golden Horde created ongoing tension. One bride who became known as Maria of the Mongols played an especially intriguing role as a woman among a strong contingent of Mongol women at court and an Eastern Orthodox Christian among Buddhists, Nestorians, and Muslims. ${ }^{28}$

Rashid al-Din also dispatched emissaries to Kashmir where the Ilkhans had real estate and military interests. Hülegü's contacts with the lost Buddhist utopia described in Tibetan, Nepali, and Indian literature, began early in his career. ${ }^{29}$ At the prosperous town of Malot, a traveler in the 1250 s came upon a temple he described as having been built by King Hülegü (Ilkhan Hülegü). ${ }^{30}$ With the establishment of the Yuan court at Dadu in 1271, Kashmir territories, home to various Buddhist sects, were divided between Hülegü and Möngke. Hülegü's territories spanned fifteen specific locations in the area of Western Tibet including the kingdom of Ladakh that was home to the Phag-mo gru-pa sect to which the Ilkhans became patrons. ${ }^{31}$ Hülegü's territories included pasturelands, market towns, and transit routes in a vital area between Tibet and Iran. ${ }^{32}$ These connections were especially critical for the development of Buddhist communities in Tabriz and throughout the Ikhanate. While many Buddhist monks at the Ilkhanid court hailed from the Uighur populations and Han Chinese circles, Rashid al-Din when

${ }^{28}$ James D. Ryan, "Christian Wives of Mongol Khans: Tartar Queens and Missionary Expectations in Asia," Journals of the Royal Asiatic Society 8, no. 3 (November 1998): 416.

${ }^{29}$ Ronald M. Davidson, "Hidden Realms and Pure Abodes: Central Asian Buddhism as Frontier Religion in the Literature of India, Nepal, and Tibet," Pacific World Journal, 3rd series, no. 4 (Fall 2002): 153-181, especially 161, 164, 167.

${ }^{30}$ Giuseppe Tucci, "Translation of the itinerary of Orgyan pa," in Travels of Tibetan Pilgrims in the Swat Valley (Calcutta: The Greater India Society, 1940), 46-47. Also see Elliot Sperling, "Hülegü and Tibet," Acta Orientalia Academiae Scientiarum Hung Tomus XLIV, no. 1-2 (1990), 145-157, 152 fn 26.

${ }^{31}$ Elliot Sperling, "Hülegü and Tibet” (1990), 145, 147, 156. Hülegü’s name appears in Tibetan sources as Hu-la-hu and Hu-la, and he is referred to as the patron of the Phag-mo gru-pa subsect or as the "Stod-Hor king."

${ }^{32}$ Iqtidar Husain Siddiqui, "The Qarlugh Kingdom in the North-Western India during the Thirteenth Century," Islamic Culture 54, no. 2 (1980), 77, 80, 82. 
compiling the Jami' al-Tavarikh selected Kashmiri monk and scholar Kamalashri to create an informed, sympathetic rendering of the Buddha's life for a predominantly Islamic audience. This required translating Buddhist terms and concepts into language and narratives already familiar to Muslim readers.

\section{CONCLUSIONS}

Tabriz in the fourteenth century defined a new pattern of world historical city that was both shaped by nomadic lifestyle and more global in political reach than previous nomadic state-builders of Central Asia. Within the Mongol Empire, the Yuan rulers adapted the Chinese bureaucratic style of governance, and the Mongol rulers of the Golden Horde and the Chagatai Khanate did not develop the cultural and diplomatic activities of the Ilkhans. The rise of Mongol authority across Eurasia suddenly elevated the status of Tabriz to a major node in a transcontinental system of commercial, cultural, and diplomatic exchange in a way that no other urban center of the period experienced. ${ }^{33}$ In this respect, Tabriz functioned as the vital center of a Mongol Empire built on the circulation of people, goods, and ideas. Shifting the political center of Iran away from Baghdad on the Tigris River and Khurasan in eastern Iran, the Ilkhans transformed the regional focus of Tabriz into a global city whose prominence, once established, would out last the Mongol's own rule as a prize symbol of political authority.

Although an area politically subordinate to the Yuan Dynasty in east Asia, Tabriz served as the political and commercial center of the Ilkhanate whose diplomatic and economic relations with Byzantium, Mamluk Egypt, Europe, and India were in many ways more extensive and direct than those managed by the Mongol court at Dadu. While there is no doubt that the Yuan supported a diverse population and encouraged experts of every background to

${ }^{33}$ Janet L. Abu-Lughod, Before European Hegemony: The World System, A.D., 12501350, (New York: Oxford University Press, 1989), 196. 
join their political efforts, the fact that Tabriz was located in a dominantly Muslim territory with complex relations to the Muslims of Egypt and the Franks of the European countries, gave the Ilkhans a major additional set of diplomatic relations to juggle as they sought to secure and extend their political authority. This project in itself speaks to the status of Ilkhanid Tabriz as a critical center in the history of world cities. The well-endowed workshop facilities of Rashid al-Din outside of Tabriz were an artistic expression of the effort to create a governing ideology and historical perspective that matched the new realities of political authority in Tabriz.

Visual evidence, as well as diplomatic, commercial, and religious records regarding the significance of Tabriz as a center of intellectual and political life in the thirteenth century, raises new questions for our understanding of early modern world history. Was the global commercial empire that made Tabriz possible a necessary precondition for the commercial expansion and technological innovation of the post-Mongol world? If we remap the circulation of people, goods, and ideas in early modern history to include Tabriz, how do Islam, Buddhism, and nomadism factor into our understanding of what has made us modern? If developments in Florence and Amsterdam mark later phases of global commercial expansion, to what extent do they depart from the model presented by Tabriz, and what might this tell us about the historical processes that we define as the emergence of modernity? Historians often identify Florence with the beginning of a new humanism. How does this compare with the focus on historical awareness and religious pluralism that we find in a work like the Jami alTavarikh?

When contact across the Eurasian expanse suddenly opened under the auspices of the Mongol Empire, geography and political investment made Tabriz a magnet for diverse commercial and intellectual interests. Out of political necessity, the rulers of Tabriz created a vision of human history that was certainly unique but also possessed both roots in the past and branches into the future. 
188 | ASIAN REVIEW OF WORLD HISTORIES 1:2 (July 2013)

As such the study of Ilkhanid Tabriz offers insight into cultural and material practices integral to the new intellectual awareness that emerged from intense and expansive encounters during the Mongol era. 